\title{
Pollination in the oil palms Elaeis guineensis, E. oleifera and their hybrids $(\mathrm{OxG})$, in tropical America ${ }^{1}$
}

\author{
María Raquel Meléndez ${ }^{2}$, William Patricio Ponce ${ }^{3}$
}

\section{ABSTRACT}

Oil palm (Elaeis guineensis) is very important in the Central and South American economies. Plants suffer from a devastating fungal disease known as "lethal decay" or "pudrición del cogollo", in Spanish. Producer countries in Africa, Asia and tropical America have developed breeding programs that seek the tolerance of this disease by plants. The hybrids Elaeis guineensis $x$ Elaeis oleifera $(\mathrm{OxG})$ are resistant, but show physiological problems that affect commercial productivity. Natural pollination in these hybrids is low and manual pollination has high labor costs. The Coleoptera order is the most numerous and diverse natural pollinator, and the Elaeidobius genus has high efficiency and specificity to oil palm species. Elaeidobius kameronicus, Elaeidobius subvittatus and Mystrops costaricensis are the insects most commonly associated with oil palm inflorescences. Dynamics in insect populations change according to palm species and weather conditions. It is necessary to understand the insect behavior and population dynamics in OxG hybrids. Thus, recent studies on oil palm pollination, insect diversity and distribution in Latin America are discussed in this study.

KEY-WORDS: Elaeidobius; Mystrops; pollinators.

\section{INTRODUCTION}

Oil palm is one of the most important crops in South and Central America. Ecuador produced 540,000 metric tons of palm oil in 2014, from approximately 270,000 hectares of crop area (PRO ECUADOR 2014). Other large producers are Malaysia and African countries (Sanz Veiga et al. 2005). Malaysia reached an area of 5.23 million hectares of oil palm, producing 0.43 million tons in 2013 (MPOC 2014).

\section{RESUMO}

Polinização em palma azeiteira Elaeis guineensis, E. oleifera e seus híbridos $(\mathrm{OxG})$, na América Tropical

A palma azeiteira (Elaeis guineensis) apresenta grande importância paras as economias da América Central e do Sul. Essa planta sofre com o ataque de uma doença fúngica devastadora conhecida como "lethal decay" ou "amarelecimento fatal", em Português. Países produtores da África, Ásia e América tropical têm desenvolvido programas de melhoramento que buscam tolerância a essa doença pelas plantas. Os híbridos Elaeis guineensis x E. oleifera $(\mathrm{OxG})$ são resistentes, no entanto, apresentam problemas fisiológicos que afetam a produtividade comercial. A polinização natural nesses híbridos é baixa e a manual tem custos de mão de obra muito elevados. A ordem Coleoptera é o polinizador natural mais numeroso e diverso, e o gênero Elaeidobius tem alta eficiência e especificidade para as espécies de palma azeiteira. Elaeidobius kameronicus, Elaeidobius subvittatus e Mystrops costaricensis são os insetos mais comumente associados às inflorescências dessa cultura. A dinâmica em populações desse inseto varia de acordo com as espécies de palma e condições climáticas. Faz-se necessário entender o comportamento desse inseto e a dinâmica de sua população nos híbridos OxG. Por isso, estudos recentes sobre a polinização da palma azeiteira, bem como a diversidade e distribuição do seu polinizador na América Latina, são discutidos neste estudo.

PALAVRAS-CHAVE: Elaeidobius; Mystrops; polinizadores.

Elaeis guineensis Jacq., the African oil palm, was introduced in the Americas first to Brazil, in the 15th century, with the arrival of African slaves and Portuguese settlers, and then to Colombia, in 1932 (Tan 1983 apud Syed 1984, Guerra 1832 apud Syed 1984).

The expansion of cultivated oil palm areas in Africa began in the 1930s, while the first seed introduction to Central America was in Costa Rica, in the 1970s (Alvarado et al. 2013). Commercial production began with the African strains Dura Deli

1. Manuscript received in Oct./2015 and accepted for publication in Feb./2016 (http://dx.doi.org/10.1590/1983-40632016v4638196).

2. Universidad de las Américas, Facultad de Ingenierías y Ciencias Agropecuarias, Carrera de Ingeniería Agroindustrial y Alimentos, Quito DM, Provincia de Pichincha, Ecuador.E-mail: maria.melendez@udla.edu.ec.

3. Universidad de las Américas, Centro de Investigación Traslacional, Quito DM, Provincia de Pichincha, Ecuador. E-mail: patricio.ponce@udla.edu.ec. 
and Pisífera/Tenera (Elaeis guineensis). Some years later, the first breeding result of Dura $\mathrm{x}$ Pisífera was introduced in Honduras (Alvarado et al. 2013). Since then, programs of genetic material exchange have begun due to a growing demand in quality and productivity.

Diversified breeding programs of Elaeis guineensis were developed to improve the production and solve disease problems, especially a bud rot complex disease known in the Americas as lethal decay (LD) or "pudrición del cogollo" (Müller et al. 2006, Alvarado et al. 2010). In the late 1970s, many countries, including Colombia, Costa Rica and Brazil, began extensive breeding programs, trying to achieve plant tolerance to lethal decay, the most devastating disease affecting oil palm in the tropical America (Müller et al. 2006, Alvarado et al. 2010).

The disease seems to be caused by an opportunistic fungi complex and its severity is influenced by soil and weather conditions. High losses of individuals and dramatic reduction in production levels have occurred in the tropical America since 1980 (Chinchilla 2010).

In Ecuador, the first cases of bud rot complex (LD) in three to four years old plants were reported in 1976, in the western lowland plantations. Later, in 1979, the disease was reported in two years old palms in the Amazonian lowlands. It peaked in 1992 and 1993, affecting 10,000 hectares in the Shushufindi and Huashito areas and, by the year 2000, none of those plants survived (Franqueville 2001). Similar problems were reported in Colombia, where, in 2007 , the disease was present in $95 \%$ of Tumaco plantations and caused a loss of 35,000 hectares of palms (Preciado et al. 2011).

The susceptibility of Elaeis guineensis to LD may be explained by the limited genetic variability of the strains used in commercial plantations. At the beginning, commercial seedlings came from only four mother plants from Africa, named Dura Deli. This strain was introduced in Malaysia and Indonesia's Botanical Gardens in the 19th century, where breeding programs began. The pollen source used for the commercial seed production was from the AVROS variety, but later other pollen sources were included, such as Ekona, Clabar, Bamenda (Cameroon), Kigoma (Tanzania) and Ghana, among others (Sterling \& Alvarado 2002).

There have been several breeding research programs seeking LD tolerance with strains from
Bamenda, Malawi, Mobai and some intraspecific crossings, as aforementioned, but with unsuccessful results (Sterling \& Alvarado 2002). Therefore, due to the impact of LD, thousands of hectares of oil palm plantations have been lost in South America (Sterling \& Alvarado 2002).

The replacement of E. guineensis strains by hybrids obtained from crosses with E. oleifera varieties such as Cuarí, Manicoré and Taisha was then pursued as an alternative for LD management (Sterling \& Alvarado 2002). Hybrids, however, have low quantity and viability of pollen and poor insect pollination, due to a high number of bracteoles that interferes with the access of insects to the female flowers. Also, the hybrids have a reduced number of male flowers and lower pollen production than the parents (Sterling \& Alvarado 2002).

The most significant breeding improvement programs have been carried out in Colombia (Corpoica; Fedepalma), Costa Rica (ASD), Brazil (Embrapa), France (Hiro, Cirad) and Malaysia (MPOB) (Sterling \& Alvarado 2002, Müller et al. 2006). In Ecuador, some breeding programs have been developed by big producers in cooperation with the Asociación Nacional de Cultivadores de Palma Aceitera (Ancupa) and Instituto Ecuatoriano de Investigación Agropecuaria (Iniap).

Breeding programs in Costa Rica, led by ASD since 1970, have looked for hybrids from Elaeis guineensis and Elaeis oleifera based on oleifera strains, such as Armuelles from Panama and Coarí, Manicoré, Tafé and Manaus from Brazil. Later, other oleifera strains were introduced, including Brunca from Costa Rica and other strains from Colombia and Panama. In 2003, a new strain from Ecuador called Taisha was introduced in Costa Rica to be tested (Araya \& Alvarado 2012). At the same time, Embrapa, in Brazil, was developing extensive programs searching for strains of Elaeis oleifera (Kunth), Cortés, for developing new hybrids with Elaeis guineensis. The first studies for commercial hybrid seed production began in 1998, with 101 crosses from 31,768 seeds obtained from the Amazonian region (Müller et al. 2006). Some hybrids showed good tolerance to LD infection, but they presented agronomic disadvantages, such as an extremely low efficiency for natural entomophilous pollination (Alvarado et al. 2013). Consequently, methods for human assisted pollination in commercial plantations were developed and are a common practice, 
despite their high economic costs due to high labor requirements (ASD 2010).

Assisted pollination of Elaeis guineensis has been a common agronomic practice in Ecuador since the early 1980s. At present, this practice is uncommon for E. guineensis, but it is essential for obtaining good yields from hybrid oil palm plantations. This agricultural activity consists of collecting pollen from aged palms, that is then dried and mixed with talc. The pollen with talc mixture is then applied on female receptive inflorescences using manual dusters (Chávez \& Rivadeneira 2003). Because of low populations of pollinating insect species, manually assisted pollination has been recommended since 2003 for young plantations in the western Andean slopes of Ecuador (Chávez \& Rivadeneira 2003)

Several reports, including Müller et al. (2006), mention that Elaeis guineensis, in America, has a low pollination efficacy. Therefore, research for introducing exotic pollinator insects such as Elaeidobius kamerunicus Faust has been pursued (Müller et al. 2006).

The purpose of this paper is to review the diversity, distribution and strategies for management of insect pollinators in commercial oil palm crops, emphasizing Ecuador and other regions.

\section{INTERSPECIFIC HYBRIDS \\ E. OLEIFERA X E. GUINEENSIS (OxG)}

Research on hybrids guineensis $x$ oleifera began in 1953, at the Instituto Agronômico do Norte (IAN), in Belém, Brazil (Botelho \& Rocha 1983). Several strains were tested for high seed production levels, good agronomic characteristics, disease resistance and high oil quality and quantity (Vieira \& Lopes 2010). However, the principal objective since the 1970s has been the search for productive strains with tolerance to lethal decay (Torres et al. 2004, Preciado et al. 2011).

A Brazilian national breeding program began in 1963, with some strains given by Hiro and others collected in Bahia and the Amazon region. Some products included Amatari, Antazes, Manés, BR 174, Perimetral Norte, Acatuba, Tefé, Anori, Moura, Tonantins, Benjamin Constant and Barcelos (Barcelos et al. 2002). Other oleifera strains from Central America tested in Colombia and Costa Rica were Armuelles from Panama and others from Indupalma, Colombia (Barba 2012). Embrapa has carried out an exhaustive research with Coarí, Manicoré, Tefé and Manaus strains (Alvarado et al. 2013). More recently, a study made by the Centro de Pesquisa Agroflorestal da Amazônia Ocidental (CPAA) showed that Manicoré is the most common hybrid used for breeding programs in Brazil, due to its advantageous agronomic aspects and high oil production (Barcelos \& Durães 1986).

In Costa Rica, the oleifera $x$ guineensis Amazon hybrid was developed with about 53-56\% of oleifera genetic contribution (Alvarado et al. 2013). This hybrid showed good results in productivity, but, like other hybrids from Brazil, it has a high number of bracteoles in the female inflorescence that apparently reduce pollination (Barba \& Baquero 2012). These bracteoles interfere in the pollinators access to the female flowers and result in lower pollination levels. In Ecuador, hybrids obtained from Taisha showed a reduction in spates in the inflorescences and good potential for breeding programs, due to their agronomic characteristics of slow growth rate, limited foliar coverage, high oil content (average of $22 \%$ ) and quality, which are desirable phenotypic characteristics in oil palms (Sakai 2002). The coverage by spates is a non-desirable characteristic, since it impedes the manual pollination process. The high number of parthenocarpic fruits by bunch in hybrids needs assisted pollination (Torres et al. 2004). These agronomic problems difficult crop management and cause high production costs. There are other oleifera strains from Ecuador, such as Ishpingo and La Boca, that can be tested in interspecific hybrids with E. guineensis (Barba \& Baquero 2012, Barba et al. 2008).

\section{POLLINATOR DIVERSITY IN ELAEIS PALMS}

The pollination of Elaeis palms depends on a large diversity of insects, mainly from six species of Coleoptera (Henderson 1986, Henderson et al. 2000). Syed (1979) mentions that entomophilous pollination is the most important method in young oil palms. Even though the effectiveness of this process depends on different factors, such as insect size and amount of hair, flower color, odors, exposure and weather conditions are also determinant for insect activity (Appiah \& Agyei 2013).

In West Africa, the natural and specific pollinators are weevils of different species, mainly from the Elaeidobius genus (Syed 1979, 
Sambathkumar \& Ranjith 2011). Some weevil species prefer male flowers, while others are more specific to female flowers. Aside from Elaeidobius, another important genus is Atheta, whose presence is restricted to flowers in the anthesis period. Elaeidobius plagiatus (Fâhraeus), E. subvittatus (Faust) and E. kamerunicus cohabitate Elaeis guineensis inflorescences. The insect populations are very different on female and male inflorescences. However, female flowers have fewer insect visitors: about $1 \%$, when compared to male flowers (Syed 1984).

Weevils are short range flyers restricted to zones that have groups of oil palm individuals. This phenomenon may explain the limited genetic variability of oil palms in Africa, since the cross pollination between different oil palm natural varieties is poor (Hayati et al. 2004). Studies in Ghana found Prosoestus minor (Marshall) on female flowers of oil palm trees, but this insect is mentioned as a distributor of pollen in the female inflorescence, and not a pollinator by itself (Appiah \& Agyei 2013). Elaeidobius kamerunicus, E. plagiatus (Fabricius), E. singularis (Faust), E. bilineatus (Hustache), E. subvittatus and rarely E. spatulifer and Prosoestus are present in the two sexes of flowers, in Cameroon. During these observations, Prosoestus sculptilis and Prosoestus minor were in large numbers on female flowers (Syed 1984). Other studies found very similar pollinating insect fauna in the Ivory Coast, including other species such as Anthocoridae sp. and Thrips sp., and bees such as Nomia sp. and Apis mellifera (Linneaus) (Hala et al. 2012).

The first commercial oil palm plantations established in Malaysia and Indonesia suffered productivity problems stemming from the assumption that anemophilous pollination was the only fruit set mechanism (Syed 1979). Studies developed by Syed (1979) showed that entomophilous pollination was important by studying the pollinator role of Elaiedobius kamerunicus, in Cameroon. Due to poor pollination results by Thrips hawaiiensis (Morgan), in Malaysia, E. kamerunicus was massively introduced in 1986 to that country, the same happening in Indonesia, in 1983. As a result, in commercial crops, the level of non-parthenocarpic fruit in the fruit set increased to approximately $36 \%$ (Appiah \& Agyei 2013).

Production improvement through introduced pollinators resulted in high hopes for the Latin America plantations where fruit set has not been satisfactory. Consequently E. kamerunicus was introduced in all oil palm producing regions of Ecuador, Costa Rica and Colombia, in 1986 (Appiah \& Agyei 2013). In Brazil, four species of Elaeidobius were introduced and the pollination capacity of $E$. singularis was tested in the Manaus region, showing an increase in fruit production (Appiah \& Agyei 2013).

Elaeis oleifera (Arecaceae) is naturally distributed in the Neotropics, and it has been used as an alternative for enriching the genetic diversity in commercial crops, by developing interspecific hybrids Elaeis oleifera $x$ Elaeis guineensis. These hybrids have tolerance to the LD disease and show other productivity advantages. Research on this oleifera and the new $\mathrm{OxG}$ hybrids found other insect species associated with these Arecaceae palms (Mariau \& Genty 1988, Appiah \& Agyei 2013). In Central America (Mexico), Venezuela, Colombia and Brazil, the most common pollinator weevils of E. oleifera and $\mathrm{OxG}$ hybrids are Elaeidobius subvittatus and Mystrops costaricensis (Gillogly) (Mondragón \& Roa 1985). Despite the common presence of these species in the region of Santo Domingo de los Tsáchilas, E. subvitattus was not identified in several studies (Genty 1985, Mondragón \& Roa 1985, Zenner 1985). Chinchilla \& Richardson (1984) mention that the native pollinator of American oil palms (Elaeis oleifera) in Central and South America is Mystrops costaricensis. Wood (1984) reports that the distribution of Mystrops costaricensis goes from Chiapas, in Mexico, to Bahia, in Brazil, and also mentions that $E$. subvitattus arrived and settled in America with the Elaeis guineensis crop development.

An extensive study was made in Colombia to assess the potential impact of introducing the new species Elaeidobius kamerunicus in this region (Mondragón \& Roa 1985). The results showed that introduced and native fauna were present in commercial oil palm plantations of Elaeis guineensis. In the male inflorescence, E. subvittatus, Mystrops costaricensis (Gyllogly), Cyclocephala discolor (Herest), Cyclocephala amazon (L.), Coproporus sp. Pos tachyporinus (Sharp), Orthoperus minutissimus (Matth.), Ahasverus sp., Smicrips sp. Por exilis (Muss), Thrips sp. and Aenigmatirum sp. (Muss) were recorded. Some differences were found in insect populations of Elaeis oleifera (Noli), where the previously mentioned species were present in 
flowers, except for C. amazon, C. discolor and Thrips sp. (Mondragón \& Roa 1985). The oleifera $x$ guineensis hybrids had less biodiversity of pollinating insects. Orthoperus sp. was present in great quantities and Aenigmatirum to a lesser extent.

In female inflorescences, there were only a few insects during the first period of anthesis. However, the insect presence increased at the peak of flower receptivity. The species visiting female inflorescences vary in diversity and quantity among E. oleifera, E. guineensis and the interspecific OxG hybrids. The biggest differences are shown in insect quantities comparing pure strains and the interspecific $\mathrm{OxG}$ hybrids, which are visited by a more limited number of insects (Mondragón \& Roa 1985). In Elaeis guineensis, the main pollinators recorded are E. subvittatus, M. costaricensis, Orthoperus, Coproporus, Ahasverus, C. discolor and Smicrips. In Venezuela, Smicripidae was reported as a particularity of this country (Labarca et al. 2009). In Noli (oleifera) only E. subvittatus was observed and, in hybrid oil palms, Orthoperus, Coproporus and Elaeidobius sp. were recorded (Mondragón \& Roa 1985).

In general, the largest quantity of insects has been recorded from Elaeis guineensis inflorescences and, in oleifera, the insect species are the same, but in lower amounts. On the other hand, Orthoperus is the most common insect in the interspecific OxG hybrid, but in low quantities (Mondragón \& Roa 1985).

Studies carried out by Embrapa, in Brazil, also showed the presence of Elaeidobius singularis and Elaeidobius plagiatus before 1986, but they were not completely efficient in reaching high fruit set levels (Müller et al. 2006). This explains why E. kamerunicus was introduced in Brazil for commercial crops. Before this introduction, there was very little information about pollinator insects in that country. The presence of E. subvittatus and two species of Nitidulidae (Mystrops costaricensis and Celetes sp.) were known (Luccini et al. 1984).

After 20 years (2004), a new research in Brazil, Guatemala, Honduras, Ecuador, Bolivia and Peru reports a larger diversity of insect pollinators. New species of the Grasidius (Curculionidae) genus were associated with oil palm inflorescences (O'Brien et al. 2004). In Brazil, at Embrapa's experimental plantations in Manaus, G. hybridus, G. Couturierius carinifrons $\mathrm{O}$ 'Brien and Becerra and $G$. Couturierius constrictoris $\mathrm{O}^{\prime}$ Brien and Becerra were described as new species with $\mathrm{OxG}$ hybrids and in oleifera palms (O'Brien et al. 2004). However, there is still a lack of information about taxonomy and behavior of Nitidulidae insects associated to oil palm inflorescences.

The Mystrops genus is the largest in the Mystropini tribe and it encompasses 33 species. Mystrops astrocaryi, Mystrops costaricensis Gillogly and Mystrops beserrai n. sp. are associated with inflorescences of Elaeis guineensis, E. oleifera and guineensis $x$ oleifera hybrids (Kirejtshuk \& Couturier 2010).

Changes in the insect population respond to several factors, including rain level, humidity, plant population, oil palm species and quantity of male inflorescences. The last census of pollinators in the Ivory Coast was conducted several years ago and it is probable that the pollinator presence and population dynamics have changed since then, due to changes in climate, oil palm genetic composition, insecticide use and presence of pollinator pathogens such as nematodes and others (Caudwell 2002, Yalamoussa et al. 2011). Caudwell, in 2002, mentions reductions in oil palm productivity and attributes this change to a possible reduction in E. kamerunicus populations, due to a parasitism of Aphenelenchoides bicaudatus and Cylindrocorpus sp. nematodes. This author suggests that this problem may be due to the endogamy of the palms, but more research is needed to confirm this hypothesis.

Reductions in pollinator populations reinforce the need of continuous behavior and community composition studies of oil palm pollinators. It was thought that the introduction of E. kamerunicus would not displace other insect species already present in America. However, Sánchez et al. (2004) mention that in the Tumaco region, in Colombia, they did not find E. subvittatus and that it may have been displaced by other Elaeidobius species introduced later.

The specific role of insects found on inflorescences also needs to be clarified. Sakai (2002) helps in part to understand the pollination potential of each insect group. This author found that Thrips spp. is a pollinator of E. guineensis, E. oleifera and their interspecific hybrids. However, their size and mobility limit their capacity to carry pollen grains. In contrast, curculionid and nitidulid beetles showed a high capacity to carry pollen grains. It seems that there is a correlation between 
Elaeidobius sp. population size and the increase in fruit set (Appiah \& Agyei 2013). Additionally, species of this genus are found in both female and male inflorescences. Both nitidulid and curculionid beetles have a post pollination development of larvae in decomposing flowers and have been observed ovipositing in male inflorescences and feeding from pollen. This relationship suggests that there is a very high dependence of these insects on Elaeis inflorescences (Appiah \& Agyei 2013).

On the other hand, bees seem to be only pollen collectors and carriers and not efficient pollinators. The Apoidea, with 18,000 species, is considered an important group of pollinators in palms. In the tropics, the most representative genera are Apis and Trigona. These genera are considered generalist pollen and nectar feeders that are attracted to flowers by color cues (Baford et al. 2011). They make their nest in the proximity of palms and transport pollen grains as a food source (Henderson et al. 2000, Sakai 2002). They are considered ovule parasites, but not in Elaeis (Sakai 2002). Considering this behavior, perhaps they contribute to pollen dispersion, but not as pollinators of Elaeis spp.

Finally, Diptera is omnipresent in flowers and some of them oviposit in the oil palm inflorescences. However, they are always found in small numbers (Baford et al. 2011). Thus, there is still much research to be done to reveal the precise role of this group of insects as efficient pollinators. Despite this, Caliphoridae, Tachinidae and Plastitomatidae are considered pollinators of some palm species (Baford et al. 2011).

\section{POLLINATORS IN COMMERCIAL OIL PALM CROPS}

Elaeidobius and Mystrops biology and palm affinity differ significantly, so it is important to review their behavior and their pollination potential (Genty 1985). As a monoecious plant, the Elaeis species depends on effective pollination mainly by insects and to a lesser extent by wind. It has been shown that the male inflorescence has an extensive associated entomofauna during anthesis, but the female flower has fewer insects visiting it (Syed 1984, Labarca \& Narváez 2009, Sambathkumar \& Ranjith 2011, Hala et al. 2012). Even if pollination is present in the Arecaceae family, the level of fruit set is not satisfactory for commercial purposes. This is the reason why some countries have tried to introduce new species of oil palm pollinators using the insects that seemed to have a greater capacity to carry pollen grains.

Before the introduction of E. kamerunicus in neotropical areas, the populations of existing Elaeidobius species had been studied by Syed (1986) and later by other authors (Prada et al. 1998, Bulgarelli et al. 2002, Sánchez et al. 2004, Labarca et al. 2009). The evidence known so far indicates that E. kamerunicus is the most efficient among all pollinators, mainly due to its capacity to carry viable pollen, which may be explained by a close relationship with oil palm flowers. E. kamerunikus coevolves with oil palm and reproduces in the male flowers. Its pollination efficacy is explained by size, as it is larger than other Elaeidobius species, such as E. subvittatus (Genty 1985). It is important to consider the affinity of these two insects for the pollination of Elaeis species, because this could be the answer for solving productivity problems. Researches with new hybrids should focus on finding plants that could attract larger numbers of insects with higher diversity of species.

Weather affects these two species differently. The E. kamerunicus population decreases with lack of rain, while E. subvittatus prefers dry weather and tends to increase its population during dry seasons (Sánchez et al. 2004, Labarca \& Narváez 2009). During the rainy season, they may also experience reduction of pollination levels, what is related to pollen injury by water drops and low insect activity caused by strong rain (Genty 1985).

Affinity of each Elaeidobius species also needs to be assessed. A study by Labarca \& Narváez (2009) showed that E. kamerunicus is a very specific pollinator. To maintain its population levels, it needs E. guineensis flowers. In contrast, E. subvittatus can successfully accomplish its life cycle in E. oleifera. Zenner (1985), and later Syed (1986), showed that the two insect species can coexist in oil palm plantations. E. subvittatus oviposition occurs over anthers of male flowers and the insect survives by eating pollen and the stem of the pollinic tube and by consuming stale flowers. E. kamerunicus is much more specific in its feeding habits, preferring the softest parts of the anther tubes, and its oviposition is limited to the surface under the anther of male inflorescences and its filament. Therefore, the E. kamerunicus population is strongly dependent on the male inflorescence population of E. guineensis. The life cycle cannot be 
completed in other flowers, such as those of cacao, banana, coffee or pineapple (Labarca \& Narváez 2009). This reaffirms the important symbiotic association between oil palms and the pollinator species that visit their inflorescences.

Additional aspects of pollinator insect behavior should be considered to understand the collaborative level between insects and oil palms, since the highest activity of Elaeidobius pollinators has been registered during the midday hours (Labarca \& Narváez 2009). Generally, the male is a more efficient pollen carrier because of its hairy body, in comparison with the female. Despite this, a larger population of female E. kamerunicus and E. subvittatus was observed in female inflorescences (Prada et al. 1998). To increase flower pollination and improve the fruit set, Syed (1986) suggests the possibility of combining the two species in plantations: E. kamerunicus during the rainy season and E. subvittatus during the dry season.

The biology of the four most important species of Curculionidae as oil palm pollinators is very similar, except for their development period. E. kamerunicus, E. subvittatus and E. plagiatus complete their life cycle in 15 days, while for E. singularis that happens in 8 days, under favorable weather conditions, in Africa and Madagascar (Mariau \& Genty 1988).

Mystrops costaricensis, described as the native oil palm pollinator of Central America, is not a very efficient pollinator in comparison with E. kamerunicus or E. subvittatus (Chinchilla \& Richardson 1984, Zenner 1985). A higher specificity of E. kamerunicus $x M$. costaricensis in E. guineensis was observed by Labarca \& Narváez (2009). In their work, E. kamerunicus represented $98.57 \%$ of the insect population in male inflorescences, in comparison with $6.66 \%$ of $M$. costaricensis. In female flowers, this difference is maintained between the two insects, with $71.31 \%$ and $21.89 \%$, respectively.

Genty (1984) mentions that while $4-40 \%$ of the E. subvittatus population carries 15 pollen grains, $15 \%$ of $M$. costaricensis carries only 2-6 pollen grains. This difference becomes significant because, in localities where M. costaricensis is numerous, fruit set decreases in comparison with places where Elaeidobius is more abundant. These facts suggest that E. subvittatus could be a more efficient pollinator. In large quantities, Mystrops could be detrimental, because it feeds on pollen and, therefore, its overpopulation could reduce the possibility of transferring viable pollen to female inflorescences. M. costaricensis has three subspecies: M. c. costaricensis from Central America, M. c. orientalis from the western part of Colombia and M. c. pacificus from the Ecuadorian and Colombian coasts. This last sub species is more active during the day (Mariau \& Genty 1988). Contrary to Elaeidobius, which is diurnal, Mystrops costaricensis is an insect with crepuscular behavior. The presence of this Mystropini in female inflorescences is generally observed between 6 and $8 \mathrm{pm}$, or during the first hours in the morning (Genty 1984).

\section{FUTURE RESEARCH}

Insect pollination in different kinds of Elaeis palms is a necessity that should be combined with other agronomic practices for increasing oil palm crop yield. There is still a lack of information about insects implicated in pollination of these plants, especially for OxG hybrids, including their distribution and behavior. The extensive introduction of hybrids to tropical America has surely changed the size of pollinator populations and their dynamics. This aspect could be reinforced by manual pollination, a common practice in commercial plantations.

Pollinator populations change constantly in response to various factors, such as weather, agronomic activities and pesticide use. The presence and number of male inflorescences in plantations are determinant factors for insect pollinators in oil palms, for being their main food source. The protandry level in OxG hybrids is low in commercial plantations, so the impact of the male flowers presence from E. oleifera or E. guineensis should be studied and kept in mind at the time of establishing commercial plantations. These aspects should be studied in depth for a better management of pollination levels in commercial crops, and the manipulation of entomophilous pollination should be considered as an alternative to reduce labor costs and increase the fruit set.

The understanding of pollinator behavior, specificity and efficacy, according to seasons, palm species and other agronomic practices, should help to develop new alternatives for using insect species as potential biological tools to replace the manual pollination of OxG hybrids in commercial plantations. 


\section{REFERENCES}

AGRICULTURAL SERVICES \& DEVELOPMENT (ASD). Nuevo híbrido OxG compacto: características varietales. San José: ASD, 2010.

ALVARADO, A.; ESCOBAR, R.; HENRY, J. El híbrido OxG Amazon: una alternativa para regiones por pudrición del cogollo en palma de aceite. Palmas, Bogotá, v. 34, n. esp., p. 305-314, 2013.

ALVARADO, A.; ESCOBAR, R.; PERALTA, F. El programa de mejoramiento genético de palma aceitera de ASD Costa Rica y su contribución a la industria. ASD Oil Palm Papers, San José, n. 34, p. 1-32, 2010.

APPIAH, S. O.; AGYEI, D. Studies on Entomophil pollination towards sustainable production and increased profitability in the oil palm: a review. Elixir Agriculture, Chennai, n. 55, p. 12878-12883, 2013.

ARAYA, E.; ALVARADO, A. Huella genética de clones compactos de palma aceitera (Elaeis guineensis): identificación con marcadores microsatélite. ASD Oil Palm Papers, San José, n. 39, p. 35-42, 2012.

BAFORD, A.; HAGEN, M.; BORCHSENIUS, F. Twentyfive years of progress in understanding pollination mechanism in palms (Areacaceae). Annals of Botany, Oxford, v. 108, n. 8, p. 1503-1516, 2011.

BARBA, J.; BAQUERO, Y. Híbridos OxG obtenidos a partir de oleíferas Taisha Palmar del Río - (Ecuador) Variedad - PDR (Taisha x Avros). Palmas, Bogotá, v. 38, n. 1, p. 1-13, 2012.

BARBA, J. et al. Evaluación agronómica de híbridos interespecificos de palma de aceite OxG (Elaeis oleifera $x$ Elaeis guineensis) provenientes de diversos orígenes americanos y su tolerancia a la pudrición del cogollo. El Coca: Palmar del Río, 2008.

BARCELOS, E. et al. Genetic diversity and relationship in American and African oil palm as revealed by RFLP and AFLP molecular markers. Pesquisa Agropecuária Brasileira, Brasília, DF, v. 37, n. 8, p. 1105-1114, 2002.

BARCELOS, E.; DURÃES, F. Dendê: uma nova opção agrícola. Brasília, DF: Embrapa, 1986.

BOTELHO, E.; ROCHA, J. Avaliação de híbridos interespecificos de Elaeis guineensis $x$ Elaeis oleifera. Belém: Embrapa, 1983.

BULGARELLI, J.; CHINCHILLA, C.; RODRÍGUEZ, R. Inflorescencias masculinas, población de Elaeidobius kamerunicus (Curculionidae), y calidad de la polinización en una plantación comercial joven de palma aceitera en Costa Rica. ASD Oil Palm Papers, San José, n. 24, p. 3841, 2002.
CAUDWELL, R. W. Polinización con insectos en palma de aceite: ¿es el momento para evaluar la viabilidad a largo plazo y la sostenibilidad del Elaeidobius kamerunicus? Palmas, Bogotá, v. 3, n. 1, p. 17-25, 2002.

CHÁVEZ, F.; RIVADENEIRA, J. Manual del cultivo de palma aceitera (Elaeis guineensis Jacq.). Quito: Ancupa, 2003.

CHINCHILLA, C. No hay evidencia de que exista alguna relación entre la incidencia y severidad de las pudriciones del cogollo en palma aceitera y el origen de las variedades plantadas en el pasado en América Tropical. ASD Oil Palm Papers, San José, n. 35, p. 16-22, 2010.

CHINCHILLA, C.; RICHARDSON, D. Situación actual de los insectos polinizadores y polinización de palma aceitera en Centro América. ASD Oil Palm Papers, San José, n. 2, p. 1-18, 1984.

FRANQUEVILLE, H. de. Oil palm bud rot in Latin America: preliminary review of established facts and achievements. Montpellier: Cirad, 2001.

GENTY, P. Estudios entomológicos con relación a la palma africana en América Latina. Palmas, Bogotá, v. 5, n. 1, p. 22-31, 1984.

GENTY, P. Polinización entomófila de la palma africana en América Tropical. Palmas, Bogotá, v. 6, n. 3, p. 90101, 1985.

HALA, N. et al. Entomofauna of oil palm tree inflorescences at LaMé Experimental Station (Côte d'Ivoire). American Journal of Experimental Agriculture, Delaware, v. 2, n. 3, p. 306-319, 2012.

HAYATI, A. et al. Genetic diversity of oil palm (Elaeis guineensis Jacq.) germplasm from Africa: implications for improvement and conservation of genetic resources. Theoretical and Applied Genetics, Stuttgart, v. 108, n. 7 , p. 1274-1284, 2004.

HENDERSON, A. et al. Pollination of Bactris (Palmae) in an Amazon forest. Brittonia, New York, v. 52, n. 2, p. 160-171, 2000.

HENDERSON, A. A review of pollination studies in the Palmae. The Botanical Review, New York, v. 5, n. 3, p. 221-259, 1986.

KIREJTSHUK, A. G.; COUTURIER, G. Sap beetles of the tribe Mystropini (Coleoptera: Nitidulidae) associated with South American palm inflorescences. Annales de la Société Entomologique de France, Paris, v. 46, n. 3-4, p. 367-421, 2010.

LABARCA, M. et al. Estructuras reproductivas y polinización entomófila en tres lotes comerciales de palma 
aceitera (Elaeis guineensis Jacq.) en el Estado de Zulia, Venezuela. Revista de la Facultad de Agronomía LUZ, Maracaibo, n. 26, p. 1-22, 2009.

LABARCA, M.; NARVÁEZ, Z. Identificación y fluctuación poblacional de insectos polinizadores en palma aceitera (Elaeis guineensis Jacquin) en el sur del Lago Maracaibo, Estado Zulia, Venezuela. Revista de la Facultad de Agronomía LUZ, Maracaibo, n. 26, p. 305324, 2009.

LUCCINI, F. et al. Importância e distribuição geográfica dos curculionideos polinizadores do Caiaué, Elaeis oleifera, no Estado do Amazonas. Manaus: Embrapa, 1984.

MARIAU, D.; GENTY, P. Contribución de la IRHO al estudio de los insectos polinizadores de la palma de aceite en Africa, América del Sur e Indonesia. Palmas, Bogotá, v. 9, n. 1, p. 33-38, 1988.

MONDRAGÓN, V.; ROA, J. Censo de entomofauna nativa asociada con inflorescencias masculinas y femeninas y análisis de polinización en palma africana (Elaeis guineensis Jacq.), palma americana (Elaeis melanococca) e híbrido interespecífico (E. guineensis $x$ E. melanococca) en Colombia. Palmas, Bogotá, v. 1, n. 1, p. 44-59, 1985.

MALAYSIAN PALM OIL COUNCIL (MPOC). Gains for oil palm 2013 performance. Global Oils and Fats Business Magazine, Singapore, v. 11, n. 1, p. 2180-4486, 2014.

MÜller, A.; FURlan, J.; CElestino, P. Contribuições da Embrapa Amazônia Oriental para o agronegócio do dendê. Belém: Embrapa, 2006.

O'BRIEN, C. H.; BESERRA, P.; COUTURIER, G. Taxonomy of Couturierius: new genus to South America, palm flower weevils in the derelomini (Coleoptera, Curculionidae). Revue française d'Entomologie, Paris, v. 26, n. 4, p. 145-156, 2004.

PRADA, M. et al. Efectividad de dos especies del género Elaeidobius (Coleoptera: Curculionidae) como polinizadores en palma aceitera. Bioagro, Barquisimeto, v. 10, n. 1, p. 3-10, 1998.

PRECIADO, C. et al. Predicción y control de la cosecha en el híbrido interespecífico Elaeis oleifera $x$ Elaeis guineensis en la zona palmera occidental de Colombia: I. Determinación del período de madurez para obtener racimos con alto contenido de aceite. Corpoica Ciencia y Tecnología Agropecuaria, Bogotá, v. 12, n. 1, p. 5-12, 2011.

PRO ECUADOR. Instituto de Promociones de Exportaciones e Inversiones. Análisis sectorial aceite de palma y elaborados. Quito: PRO ECUADOR, 2014.
SAKAI, S. A review of broodsite pollination mutualism: plant providing breeding sites for their pollinators. Journal of Plant Research, Tokyo, n. 115, p. 161-168, 2002.

SAMBATHKUMAR, S.; RANJITH, A. M. Insect pollinators of oil palm in Kerala with special reference to African weevil, Elaeidobius kamerunicus Faust. Pest Management in Horticultural Ecosystems, New Delhi, v. 17, n. 1, p. 14-18, 2011.

SÁNCHEZ, E. et al. Evaluación de poblaciones de polinizadores y su relación con la formación de racimos en la zona de Tumaco, Colombia. Palmas, Bogotá, v. 25, n. esp., p. 84-92, 2004.

SANZ VEIGA, A. et al. A dendeicultura na visão do setor privado. In: SEMINÁRIO INTERNACIONAL "AGRONEGÓCIO DO DENDÊ: UMA ALTERNATIVA SOCIAL, ECONÔMICA E AMBIENTAL PARA O DESENVOLVIMENTO SUSTENTÁVEL DA AMAZÔNIA", 2005, Manaus. Anais... Belém: Embrapa, 2005. p. 17-43.

STERLING, F.; ALVARADO, A. Historia de las colecciones de germoplasma de palma aceitera de ASD de Costa Rica. ASD Oil Palm Papers, San José, n. 24, p. 17-23, 2002.

SYED, R. A. Los polinizadores de la palma africana. Palmas, Bogotá, v. 3, n. 1, p. 19-64, 1984.

SYED, R. A. Studies on oil palm pollination by insects. Bulletin of Entomological Research, Cambridge, v. 69, n. 2, p. 213-224, 1979.

SYED, R. Factibilidad de la introducción de E. kamerunicus en Colombia. Palmas, Bogotá, v. 1, n. 1, p. 11-15, 1986.

TORRES, M. et al. Evaluación del comportamiento de los híbridos interespecíficos Elaeis oleifera x Elaeis guineensis, en la plantación de Guaicaramo S.A. Colombia. Palmas, Bogotá, v. 25. n. esp., p. 350-357, 2004.

VIEIRA, R.; LOPES, R. BRS Manicoré: híbrido interespecífico Caiaué e do dendezeiro africano recomendado para áreas de incidência de amarelecimentofatal. Manaus: Embrapa, 2010.

WOOD, B. J. Nota sobre los insectos polinizadores de la palma africana en América Central y del Sur. Palmas, Bogotá, v. 5, n. 2, p. 19-22, 1984.

YALAMOUSSA, T.; HERVÉ, K.; HALA, N. Biology of Elaeidobius Kamerunicus and Elaeidobius Plagiatus (Coleoptera: Curculionidae) main pollinators of oil palm in West Africa. European Journal of Scientific Research, Victoria, v. 49, n. 3, p. 426-432, 2011.

ZENNER, I. Estudio inicial de las poblaciones larvales de Elaeidobius subvittatus en Colombia. Palmas, Bogotá, v. 3, n. 1, p. 85-101, 1985. 